\title{
THE PRICING SYSTEM OF RED ONION AND RED CHILI COMMODITIES
}

\author{
Heny Kuswanti Suwarsinah ${ }^{* 1}$, Naafi Fatimah Harwanti**), Hastuti**), and Muhammad Firdaus ${ }^{* *}$ \\ *) School of Business, Bogor Agricultural University \\ Pajajaran Street, Bogor 16151 \\ ${ }^{* *}$ Departement of Economics, Faculty of Economics and Management, Bogor Agricuture University \\ Agatis Street Wing 4 Level 5, Bogor Agricuture Univesrsity Campus, Darmaga Bogor 16680 \\ ${ }^{* * *}$ Department of Resources and Environmental Economics, Faculty of Economics and Management, \\ Bogor Agricuture Univesrsity \\ Agatis Street, Bogor Agricuture Univesrsity Campus, Darmaga Bogor 16680
}

\begin{abstract}
The prices of red chili and red onion commodities tend to fluctuate and have high margin rates, causing inefficiency of prices. On the other hand, the demand for red chili and red onion will increase as the number of population increases. This study aimed to analyze the factors and behaviors that can affect the pricing system on red onion and red chili in East Jakarta by using the Vector Error Correction Model and Game Theory. The results showed that the producer and wholesale prices of red onion and red chili commodities contribute to the price discovery at the consumer level. Maximum profit is achieved by retail merchants when they adopt prices in collusion as a dominant strategy.
\end{abstract}

Keywords: red onion, red chili, game theory, price, VECM

\begin{abstract}
Abstrak: Harga komoditas cabai merah dan bawang merah cenderung berfluktuasi dan memiliki tingkat margin tinggi sehingga menimbulkan tidak efisiennya harga yang ditetapkan. Di sisi lain permintaan cabai merah dan bawang merah akan terus meningkat seiring dengan peningkatan penduduk. Tujuan penelitian ini adalah untuk menganalisis faktor-faktor dan perilaku yang dapat memengaruhi sistem penetapan harga komoditas bawang merah dan cabai merah di Jakarta Timur dengan menggunakan Vector Error Correction Model dan Game Theory. Hasil penelitian ini menunjukkan harga produsen dan harga grosir komoditas bawang merah dan cabai merah berkontribusi besarterhadap pembentukan harga pada tingkat konsumen. Keuntungan maksimum diperoleh pedagang eceran ketika pedagang eceran menerapkan harga secara berkolusi sebagai strategi dominan.
\end{abstract}

Kata kunci: bawang merah, cabai merah, game theory, harga, VECM

\footnotetext{
${ }^{1}$ Corresponding author:

Email: hastutisiregar@gmail.com
} 


\section{INTRODUCTION}

The GDP growth rate of the agricultural sector reached $0.58 \%$ in the fourth quarter of 2016 and increased in the first quarter of 2017 by $13.59 \%$ (the Ministry of Agriculture of the Republic of Indonesia, 2017). The Indonesian Center for Agricultural Socioeconomic and Policy Studies (2015) stated that the average GDP growth rate of the agriculture sector reaching up to $3.56 \%$ per year has also encouraged the increase in the national GDP. This is caused by the use of data bases with constant prices as well as the increased production of horticulture, food, and plantation.

One cause of inflation is the constraint of seasonal harvest that has an impact on the domestic stock supply and geographical factor that hinders the process of distribution. In the Strategic Plan of the Directorate General of Horticulture for 2015-2019, it is stated that red onion and red chili are the types of horticulture commodities that will become the strategic issues and receive special attention from the government and business actors, thus contributing to the growth of the national economy.

The Center for Data and Information System of the Ministry of Agriculture of the Republic of Indonesia (2016) explained that domestic market demand and export opportunity on red onion and red chili commodities tend to increase. Figure 1 shows the production increase of red onion reaching 1.23 million tons with the support of 122 thousand ha of harvested areas and that of red chili reaching 1.92 million tons with the support of 256 thousand ha of harvested areas in 2015 .

The synergy between short-term policy in the form of tax and duty incentives and medium-term policy in the form of increased agricultural productivity and long-term policy in the form of adaptation and mitigation of climate change can create price stability and agricultural product supply to ensure the welfare of community (Sujai, 2016). Therefore, it is necessary to synergize the price discovery mechanism formed between demand and supply in the market. Prices at the wholesale level have a great influence on the pricing at the consumer level.

Red chili is a group of vegetable commodities commonly grown by farmers both traditionally and intensively in lowland rice fields (Saptana et al. 2010). The total productivity of red onion and chili commodities in general in Indonesia is described by Figure 2. It can be seen that in the period of 2009-2015, fluctuations in production hadbeen experienced by both commodities. Red onion had the highest productivity rates in 2013 and 2014 at 10.22 ton per hectare, while chili had the highest productivity rates in 2012 and 2015 with the same amount of 7.49 tons per hectare in Indonesia.

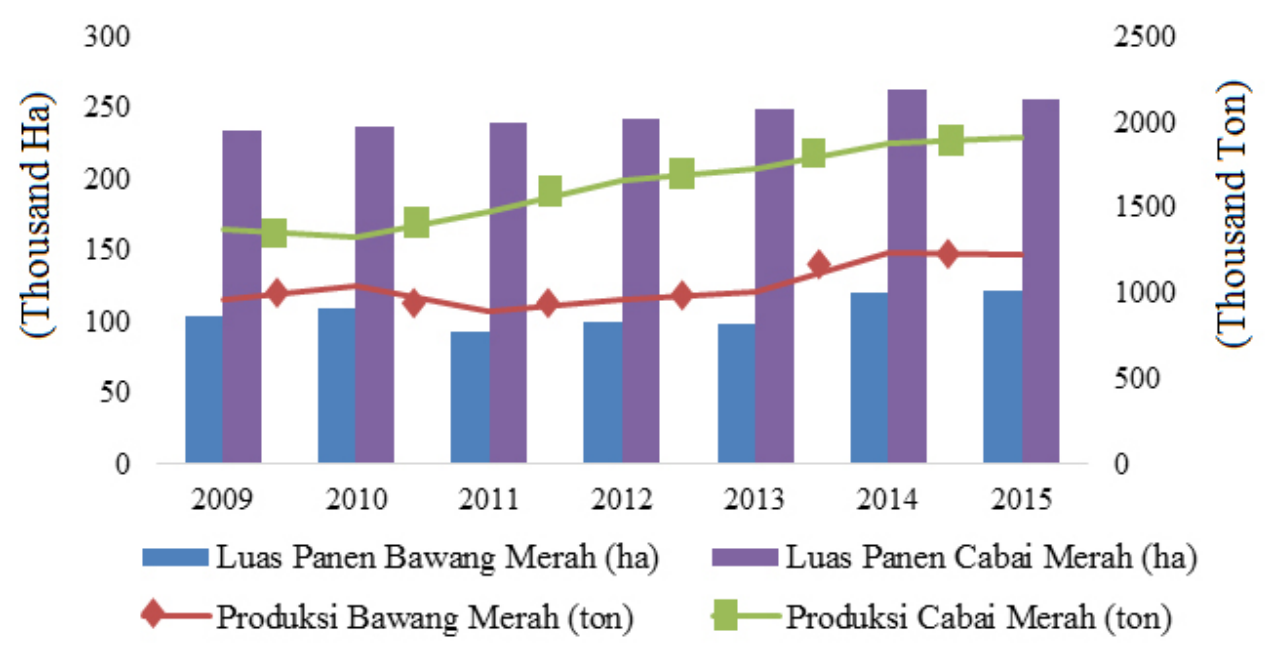

Figure1. Production development and harvested areas of red onion and red chili in Indonesia in the period of 20092015 (Statistics Indonesia and Pusdatin, 2015) 


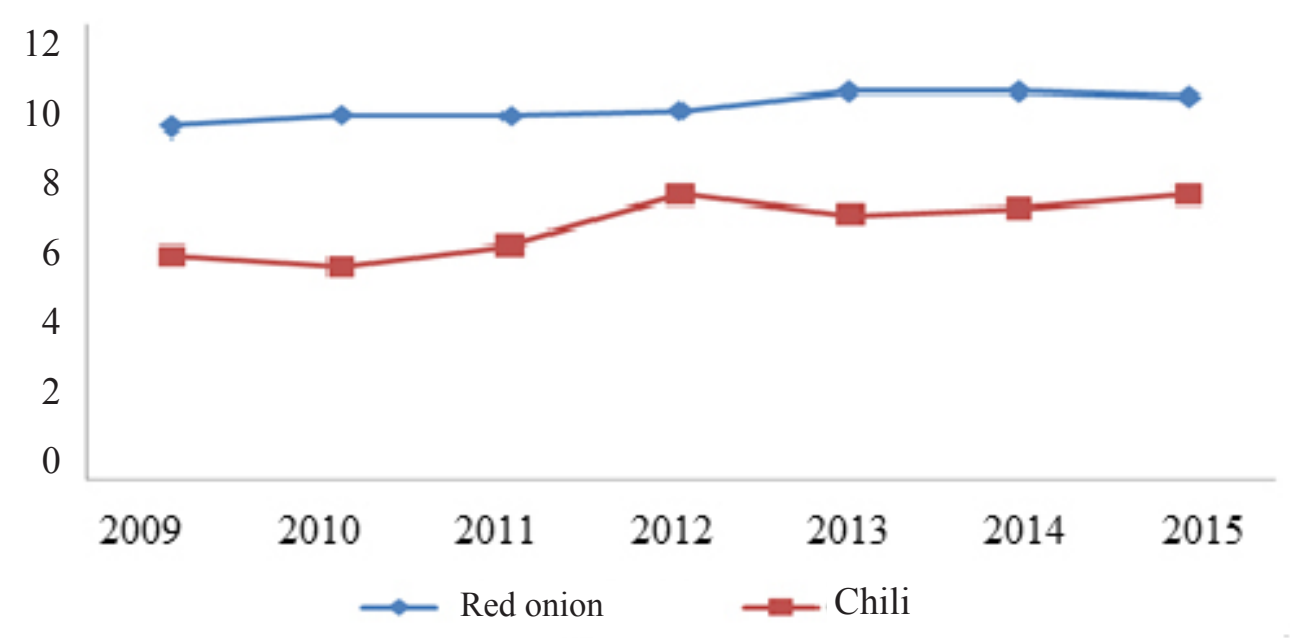

Figure 2. Total productivity of red onion and chili in Indonesia from 2009 to 2015 (Statistics Indonesia, 2015)

Java Island is the center of horticultural production with red onion commodity in Central Java reaching an average production of 432,813 tons and red chili in West Java reaching an average production contribution of 228,368 tons (Statistics Indonesia, 2016). The high level of supply originating from domestic products, convergence with the policies of the Ministry of Agriculture, and inadequate price policy has led to the need for price and fundamental approach combination to be applied to the red onion and red chili commodities (Nuryatiand and Farid, 2016). The prices of staple goods according to Raharja and Manurung in Indrawati (2013) are always monitored by the government because the role of government is to oversee the state of the economy.

On the other hand, the high consumption level in various regions of Indonesia with limited production amount and geographical condition has led to a number of issues arising from both commodities, especially at the end or the beginning of the year. The marketing efficiency occurring in the red onion and red chili market needs effective and efficient coordination between the economic actors, such as wholesale merchants and retailers. According to Susanawati et al. (2015), consumer market has a dominant influence (leading) in the pricing.

The average national price of red onion commodity at the producer level from January 2011 to December 2015 amounted to IDR14,431 per kilogram and at the consumer level at IDR25,959 per kilogram with an average margin of IDR11,528 per kilogram. The average national price of red chili commodity at the producer level from January 2011 to December 2014 amounted to IDR18,788 per kilogram, while the price at the consumer level was IDR49,784 per kilogram with an average margin of IDR30,997 per kilogram. This high amount of margin has led to the inefficiency of price determined.

Red chili demand will continue to increase as the population increases, and the same applies to red onion commodity. The production of red onion in 2016 experienced an increase of $3.93 \%$ per year, supported by an increase in harvested areas of $7.16 \%$ per year, resulting in an increase in productivity of $1.05 \%$ per year and experiencing a surplus of 997 thousand tons (Statistics Indonesia, 2016).

DKI Jakarta is one of the migration destination cities of the population of Indonesia. The appeal for the people to migrate to the capital is the high regional minimum wage and other easily accessible full facilities in DKI Jakarta, thus supporting the formation of net consumers of agricultural commodities. One of the areas of Jakarta with the highest population compared to the other areas is East Jakarta with a population of 2.86 million people in 2016 (Statistics Indonesia Regional Office of East Jakarta, 2016) and population density of $27.94 \%$ of the total\%age of DKI Jakarta (Statistics Indonesia, 2015). 
The population density in East Jakarta increased significantly with population growth reaching 15,224 people per $\mathrm{km}^{2}$ in 2016 (Statistics Indonesia Regional Office of East Jakarta, 2016). The high number of population in East Jakarta indicates the assumption that the consumption level of East Jakarta population of horticultural products is higher compared to other parts of DKI Jakarta.

Nuryani and Yudha in Nauly (2016) proposed that the formulation and implementation of price stabilization policy require information on price fluctuations and disparities caused by price changes in a market which are transmitted partially to the prices determined by other markets. The study conducted by Ardito (2012) stated that the threat to distribution pattern will have a major impact on the availability of goods that can affect the price level, so it is important to see the price transmissions occurring between the economic actors. Therefore, this study aimed to: (1) analyze the influence of producer price, wholesale price, supply, and fuel price on the pricing of red chili and red onion at the consumer level in the traditional markets of East Jakarta, and (2) analyze market behavior in the determination of red chili and red onion selling price strategy in the traditional markets of East Jakarta.

\section{METHODS}

This study used primary and secondary data. The primary data taken consisted of merchant behavior in the pricing, the determination of selling price strategy, and inter-marketing institution strategy. The data were obtained using a questionnaire list to interview the wholesale merchants of red onion and curly red chili in Kramat Jati Central Market and the retailers making purchases to the wholesale merchants, and this was considered to represent the study population. Sampling was done by using the purposive technique. This technique was chosen based on the considerations in accordance with the research objectives (Juanda, 2009).

This study used secondary data of monthly time series data from 2011 to 2016. The secondary data were obtained from relevant sources i.e. Statistics Indonesia, the Industry and Trade Agency (Disperindag) of DKI Jakarta, the Agriculture Agency of Food Security and Horticulture (Disperta) of Brebes District, the Agriculture and Horticulture Agency (Disperta) of West Java Province, Kramat Jati Central Market (PIKJ), the State Owned Enterprise of Pasar Jaya DKI Jakarta, another literature relevant with the study. The consumer prices of East Jakarta used the approach on the consumer prices of DKI Jakarta. The price data used in the game theory analysis were the nominal prices most used by the merchants. Explanation of variables in the study in Table 1.

\section{Vector Error Correction Model (VECM) Analysis}

The first objective of this study was to examine the impacts of supply factors on horticultural commodity price variables including red onion and curly red chili. The evaluation of the first objective used the Vector Error Correction Model (VECM) method. This study used the variables of red onion consumer price (LnPKB) andcurly red chili price (LnPKC) in DKI Jakarta, producer price at five provincial centers (LnPP), wholesale price at Kramat Jati Central Market (LnPG), supply (LnS), andFuel (LnBBM). The VECM model can generally be seen as follows (Firdaus, 2011):

$$
\Delta \mathrm{Y}_{\mathrm{t}}=\mu_{0 \mathrm{x}}+\mu_{1 \mathrm{x}} \mathrm{t}+\alpha_{\mathrm{x}} \beta^{\prime} \mathrm{Y}_{\mathrm{t}-1}+\sum_{\mathrm{i}=1}^{\mathrm{k}-1} \tau_{\mathrm{ik}} \Delta \mathrm{Y}_{\mathrm{t}-\mathrm{i}}+\varepsilon_{\mathrm{t}}
$$

Table1. Explanation of variables in the study

\begin{tabular}{llll}
\hline Variable & \multicolumn{1}{c}{ Description } & \multicolumn{1}{c}{ Unit } & \multicolumn{1}{c}{ Source } \\
\hline PKB & Red Onion Price at Consumer Level & Rupiah per Kg & Disperindag of Jakarta \\
PKC & Curly Red Chili Price at Consumer Level & Rupiah per Kg & Disperindag of Jakarta \\
PP & Red Onion/Curly Red Chili at Producer Level & Rupiah per Kg & Disperta of Brebes District, Disperta of \\
& & & West Java Province \\
PG & Red Onion/Curly Red Chili at Wholesale Level & Rupiah per Kg & PIKJ \\
S & Red Onion/Curly Red Chili Supply at Wholesale & Ton & PIKJ \\
& Level & & \\
BBM & Fuel Price & Rupiah per Liter & Statistics Indonesia \\
\hline
\end{tabular}


Description: $Y_{t}$ (Endogenous variable vector at the first difference of the thmonth); $\mu_{0 x}$ (Intercept vector); $\mu_{1 \mathrm{x}}$ (Regression coefficient vector); $\mathrm{t}$ (Time trend); $\quad \alpha_{x} \beta^{\prime} \quad$ (Long-termcointegration); $Y_{t-1}$ (In-level variable); $\tau_{\mathrm{ik}}$ (Regression coefficient matrix); k-1(order of VECM from VAR); $\varepsilon_{\mathrm{t}}$ (Error term).

The five variables used to analyze the factors influencing retail merchants in determining the selling prices of red onion and curly red chili to the consumers in East Jakarta were divided into two models in this study. The models used in this study were adopted from the Sahara and Wicaksana models in Ruslan (2016). The VECM restriction model used in analyzing consumer price discovery is as follows:

$\begin{aligned} \Delta \operatorname{lnPK} \mathrm{t}_{\mathrm{t}}= & \alpha_{0}+\sum_{\mathrm{i}=1}^{1} \alpha_{1} \ln \mathrm{PG}_{\mathrm{t}-1}+\sum_{\mathrm{i}=1}^{1} \alpha_{2} \ln \mathrm{ln}_{\mathrm{t}-1}+\sum_{\mathrm{i}=1}^{1} \alpha_{3} \ln \mathrm{S}_{\mathrm{t}-1} \\ & +\sum_{\mathrm{i}-1}^{1} \alpha_{4} \ln \mathrm{nBM}_{\mathrm{t}-1}+\gamma \mathrm{ECT}_{\mathrm{t}-1}+\varepsilon_{\mathrm{t}}\end{aligned}$

Description: $\mathrm{PK}_{\mathrm{t}}$ (Commodity retail price per kilogram of the th period $(\mathrm{Rp} / \mathrm{kg})$ ); $\mathrm{PG}_{\mathrm{t}}$ (Commodity wholesale price per kilogram of the th period $(\mathrm{Rp} / \mathrm{kg})) ; \mathrm{PP}_{\mathrm{t}}$ (Commodity producer price per kilogram of the th period $(\mathrm{Rp} / \mathrm{kg})$ ); $\mathrm{S}_{\mathrm{t}}$ (Commodity supply at wholesale merchants per ton of the th period (Ton)); $\mathrm{BBM}_{\mathrm{t}}$ (Fuel price per liter of the th period $(\mathrm{Rp} / \mathrm{lt})) ; \alpha_{\mathrm{ij}}$ (Regression coefficient of VECM); $\varepsilon_{t}$ (Error term in the th period); $\mathrm{t}$ (Monthly period from January 2011 to December 2016).

\section{Game Theory Analysis}

The second objective of this study was to analyze the market behavioral strategies in the determination of red onion and curly red chili commodities. The analysis used to observe the objective utilized game theory. The assumption in this game is common knowledge or knowledge in general (Ruslan, 2016). The purpose of this assumption is that not only each player knows the rules of the game but also other players and other information. In addition, through this approach, the price discovery strategies conducted at the wholesale merchant and retailer levels can be seen. The Pareto optimum foundation was used as the indicator that the occurrence of change would lead to a loss for all actors. This analysis can be explained in the payoff matrix listed in Table 2.
Table 2 . The pricing strategy matrix by retailers in a single market

\begin{tabular}{lcc}
\hline \multirow{2}{*}{ Retailer $_{i}$} & \multicolumn{2}{c}{ Retailer $_{\mathrm{i}} 1$} \\
\cline { 2 - 3 } & Competitive price $_{1}$ & Market price \\
\hline Market price & $\alpha_{1}, \alpha_{2}$ & $\alpha_{2}, \alpha_{2}$ \\
Competitive price & $\alpha_{1}, \alpha_{1}$ & $\alpha_{2}, \alpha_{1}$ \\
\hline
\end{tabular}

Note: $\alpha_{i}=$ payoff strategy

Red chili and red onion are strategic commodities in Indonesia; however, in their development, the major problem faced in the development of both commodities is price fluctuations. Price fluctuations are very sharp due to seasonal production, resulting in the two commodities having perishable nature, which is easily damaged or rotten and not durable and vulnerable to weather changes. This causes price fluctuations in the production center. The first objective of this study was to analyze the pricing of red chili and red onion at the consumer level by retailers. The analysis was conducted using the Vector Error Correction Model (VECM) method to determine the factors on the determination of corn and soybean prices. The interdependence between the wholesale merchants and retailers such as red onion suppliers has resulted in differences in strategy taken by each actor influencing the strategic decisions of other actors. Therefore, the second objective of this study was to analyze the market behavior in the pricing by using the Game Theory analysis. Based on that description, the framework of this study can be seen in Figure 3.

Based on the explanation, the hypotheses in this study are as follows: It is assumed that there is a price disparity received by the consumers of red chili and red onion commodities. There is a deviation of market behavior in the pricing from wholesale merchants and retailers to consumers.

\section{RESULTS}

\section{The General Condition of Kramat Jati Central Market}

The Provincial Regulation of DKI Jakarta No. 3 of 2009 dated January 28, 2009 on Market Area Management in the Special Capital Region of Jakarta has become the legal foundation for the establishment of Kramat Jati Central Market. Rejuvenated on March 1, 2003 to December 31, 2008 using a sharing system with a third party of PT Tritunggal Sentra, Kramat 
Jati Central Market has a total area of 14.7 hectares, $83,605 \mathrm{~m}^{2}$ building area, $14,737 \mathrm{~m} 2$ parking area and capacity of 238 trucks, 637 cars, and 600 motorcycles. Kramat Jati Central Market is a large trading center facility of vegetables and fruits in DKI Jakarta, and it is comprehensive with the necessary complementary facilities and the filling of the trade is left to the private potentials and related traders (PIKJ, 2017).

According to PIKJ (2017), the commodities sold in Kramat Jati Central Market have no information on their origin because the origin area labels are not stated, the quality of goods from supplier areas is unknown, and consumers are the injured party. Also consumers cannot receive information on the quality of goods purchased because there is no quality submission made from the supplier areas or related agencies. Sales behavior in Kramat Jati Central Market is divided into packaging, storage, and transportation. The transportation of goods from the regions or from Kramat Jati Central Market to the destination areas has not experienced standardization in shelves or partitions to minimize damages.

Inflation in the economy is a process of increasing prices of goods with a positive trend and affecting the prices of other goods, and it is caused by various factors, including higher demand level than supply level, faltering distribution process, and liquidity problems in the form of abundance of money in the market. The Inflation Central Agency calculates inflation through the Consumer Price Index (CPI), which is the average price of a determined set of goods (Statistics Indonesia, 2016). Based on the Regulation of the Minister of Finance No. 93/PMK.011/2014 on the Inflation Targets of 2016-2018 stipulated by the government, the values are, respectively, $4 \%, 4 \%$, and $3.5 \%$ with $\pm 1 \%$ deviation. Controlled inflation targets indicate signs of economic growth as indicated by the increase in people's purchasing power.

\section{Consumer Price Responses of Red Onion and Curly Red Chili to Research Variable Impulses}

The types of horticultural crops that have the property to fulfill the basic needs of households and whose role is important in the formation of one aspect that shapes the inflation rate in Indonesia are red onion and curly red chili commodities. The variables in this study included the wholesale price, producer price, supply, and fuel price. These four variables have a major influence on the price discovery of retail merchants. In this section, we will discuss the model used for red onion and curly red chili commodities to measure the magnitude of other variable shocks on the prices at the consumer level of both commodities over the next 30 periods.

The shock in wholesale price was directly responded in a significantly positive manner by the retail price of red onion in the first period at $0.174771 \%$ and in the second period at $0.208451 \%$. The following periods showed positive responses on average. An increase in wholesale price will lead to an increase in consumer price. This result is reinforced by previous studies conducted by Njuguna (2015) and Paul et al. (2016), stating that price information also determines the integration and transmission of the occurring prices.

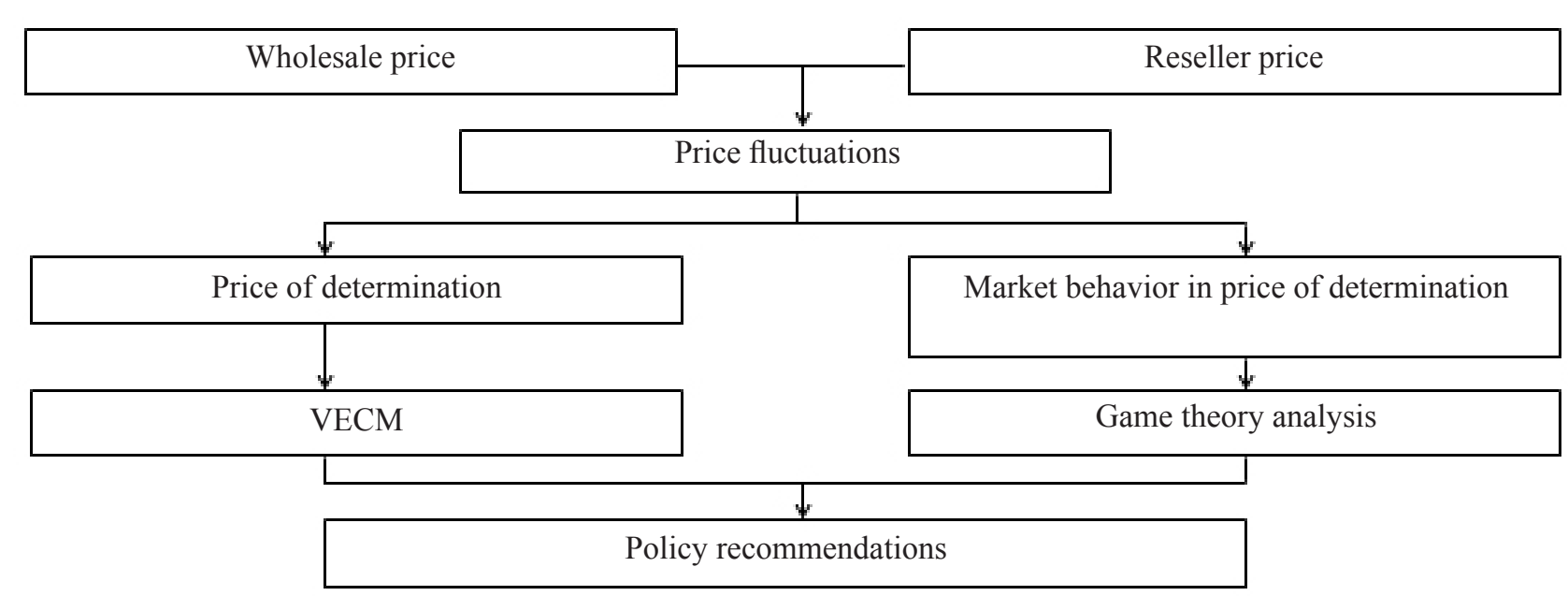

Figure 3. Research framework 
The price of red onion at the consumer level insignificantly and positively responded to any impulse from the producer price from the beginning to the end of the period. The retail price response of red onion to the producer price shock was 0.178468 in the second period. Any producer price increase of red onion by one standard deviation will increase the retail price level of red onion insignificantly at $0.178468 \%$. The long-term equilibrium occurred in the 23 rd period at $0.163877 \%$. Improvement of the market information system and storage facility provision of red onion needs to be done to avoid any disparity in the selling price discovery between producer and retail markets in the short term (Nuraeni et al. 2015).

Each supply shock was significantly negatively responded by the retail price of red onion from the beginning to the end of the period. The response given by the retail price of red onion was $-0.083855 \%$ to the wholesale supply shock of red onion in the first period and then $-0.140094 \%$ in the second period. The increase in the wholesale supply of red onion by one standard deviation will reduce the retail price of red onion by $0.140094 \%$. The $23 \mathrm{rd}$ period is the long-term equilibrium period ranging at $-0.119639 \%$. Rajendran (2015) in his study on the vertical price transmission process using a case on the red onion market in India revealed that there is a greater power owned by the retail merchants due to large supply and excessive profit margins.

The first period of the retail price of red onion responded to the fuel price shock at $0.004119 \%$. The retail price response of red onion to the fuel price in the second period amounted to $0.008273 \%$. The value indicates that an increase in the fuel price by one standard deviation will raise the retail price of red onion significantly by $0.08273 \%$. In the following period, the retail price of the red onion responded negatively to the fuel price shock at $0.004496 \%$ and began to stabilize in the 25 th period at $-0.004750 \%$. This result is different from the theory explaining that an increase in the fuel price will increase commodity price. This result is reinforced by previous studies conducted by Rajendran (2015) and Amanda (2016) stating that access to infrastructure, market condition, supply chain, and distribution disruption caused by geographical distances has more influential relation on the determination of market selling price. The shock impacts of research variables on the prices at the consumer level of red onion commodity in Figure 4.
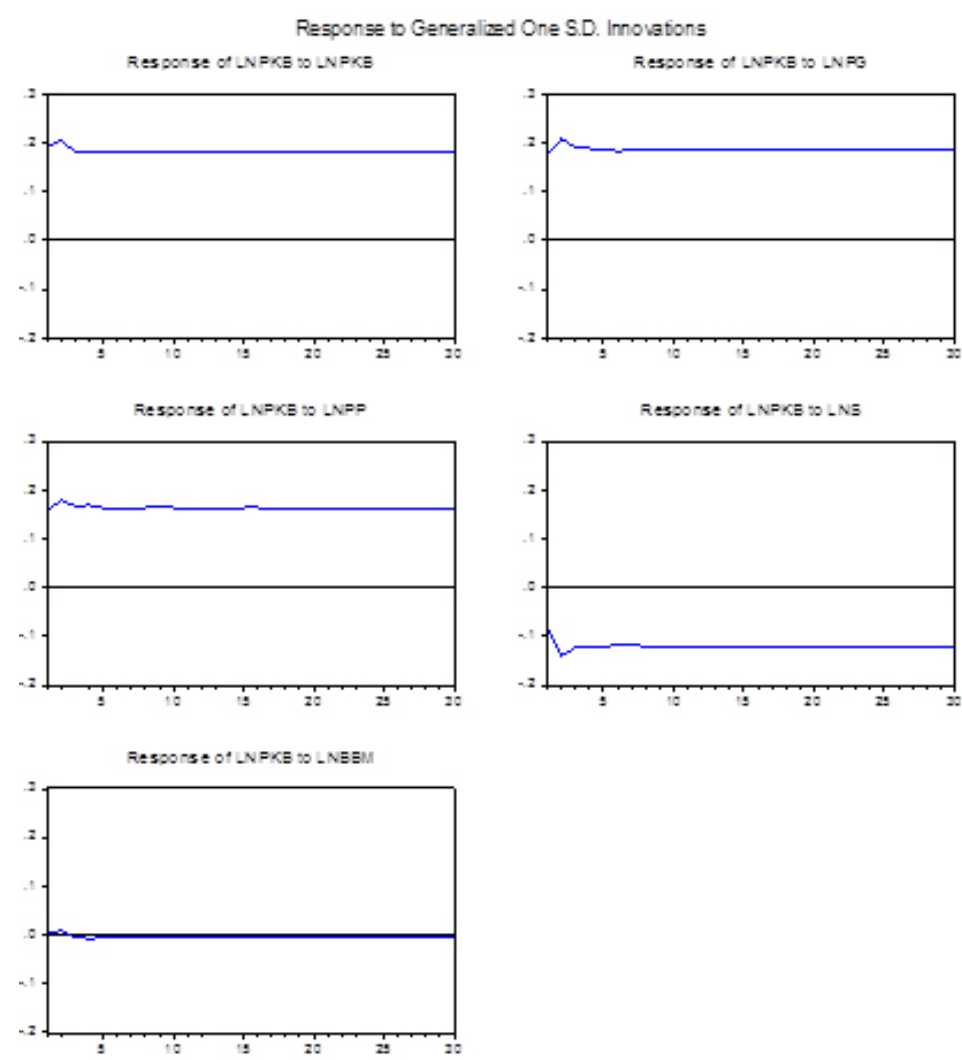

Figure 4. The shock impacts of research variables on the prices at the consumer level of red onion commodity 
Based on the results of IRF analysis with the identification based on the Generalized Decomposition, it can be concluded that the price response at the consumer level of red onion is significantly and positively the highest against the wholesale price of red onion, whereas the price response at the consumer level of red onion is significantly and negatively the highest against the red onion supply at the wholesale level. The most responsive equilibrium period of the retail price of red onion occurred when there were impulses from wholesale price, producer price, and red onion supply owned by the wholesale merchants in the 23rd period. This incident explains that the right policy for the stabilization of the consumer price of red onion is to control the wholesale price and supply of red onion commodity because they are capable of giving the highest impacts.

The IRF results for curly red chili commodity are not much different from the IRF results for red onion commodity. In Figure 5, the wholesale price shock is instantly responded in a significantly positive manner to the retail price of curly red chili in the first period at $0.171546 \%$ and in the second period at $0.318990 \%$. The following period on average shows a positive response. An increase in the wholesale price of curly red chili will lead to an increase in the price received by consumers. This result is reinforced by previous studies conducted by Elvira (2016) stating that there is a longterm relationship between wholesalers and consumers.

The retail price response of curly red chili to the producer price shock was 0.302224 in the second period. The price at the consumer level of curly chili significantly and positively responded to any impulse from producer price from the beginning to the end of period. It shows that any increase in the producer price of red onion by one standard deviation will increase the retail price of red onion by $0.302224 \%$. The long-term equilibrium occurred in the 14 th period at $0.289917 \%$.
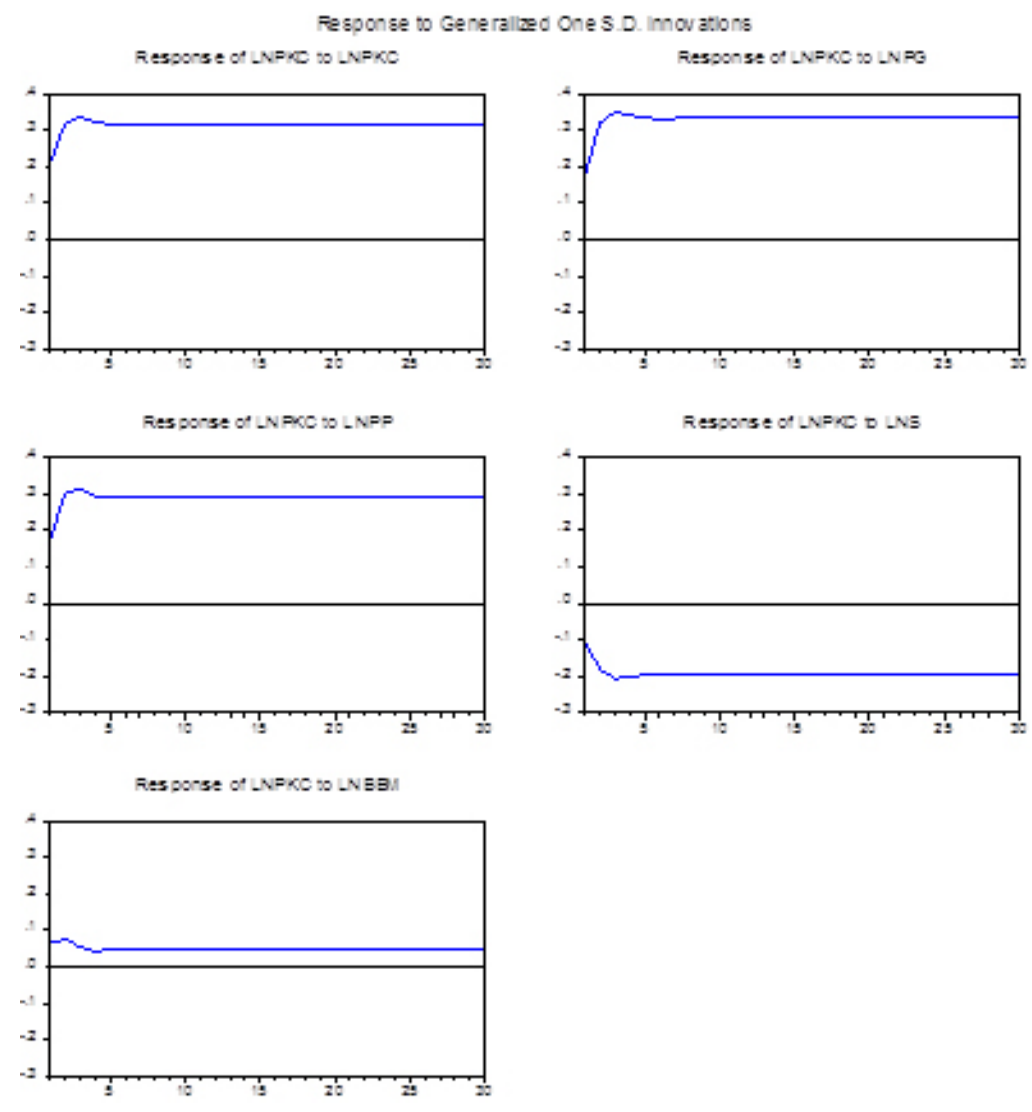

Figure 5. The shock impacts of research variables on the prices at the consumer level of curly red chili commodity 
Each supply shock was significantly and negatively responded by the retail price of curly red chili from the beginning to the end of the period. The response given by the retail price of red curly chili was $-0.102062 \%$ against the wholesale supply shock of red curry chili in the first period and subsequently equal to $-0.180354 \%$ in the second period. It shows that an increase in supply owned by the wholesale merchants of red curry chili by one standard deviation will reduce the retail price of red chili by $0.180354 \%$. The 13 th period is a long-term equilibrium period ranging at $-0.196618 \%$. Fitriana (2016) explained that the total seasonal chili production has a great influence on the market pricing. The high production during the rainy season causes the price of chili to decline and the low production in the dry season causes the price of chili to increase. This can result in fluctuations in the prices received by the marketing actors of chili commodity.

The first period of the retail price of curly red chili responded to fuel price shock at $0.065508 \%$. The retail price response of curly red chili to fuel price in the second period amounted to $0.076446 \%$. The value indicates that an increase in the fuel price by one standard deviation will raise the retail price of red onion significantly by $0.076446 \%$. In the following period, the retail price of red onion responded stably to the fuel price shock in the 13th period at $0.047551 \%$. The study conducted by Agustian and Anugrah (2008) on the development of price and marketing chain of red chili in West Java Province has shown that the length of marketing chain causes the inequality of marketing net profit margin between collectors and wholesale merchants.

Based on the results of IRF analysis of curly red chili commodity with the identification based on the generalized decomposition, it can be concluded that the price response at the consumer level of curly red chili is significantly and positively the highest against the wholesale price of curly red chili, while the priceresponse at the consumer level is significantly and negatively the highest against the supply at the wholesale level. The most responsive equilibrium period of the retail price of curly red chili occurred when there were impulses from the wholesale price, producer price, and supply of curly red chili owned by wholesale merchants and fuel price in the 13th period. This event explains that the right policy for the stabilization of consumer price of red onion is to control the wholesale price, producer price, and supply of curly red chili commodity and fuel cost because they are capable of giving the highest impacts.

The highest chili price fluctuation occurs in December and the lowest one occurs from July to August. This is due to the planting time of curly red chili which is affected by the weather. The development of off-season cultivation, planting arrangement and encouragement to grow curly red chili at the commodity production centers outside Java need to be done by the government to overcome the lack of supply and to achieve small price disparity of chili (Nauly, 2016).

\section{The Decomposition of Research Variable Effects on the Consumer Prices of Commodities}

Each variable contributes differently to the consumer price discovery of commodities. The length of the period used to see the decomposition of research variable effects on the consumer prices of commodities was 30 periods. The first period of the consumer price variable of red onion was only influenced by the same variable which was equal to $100 \%$. The largest contribution was generated by the wholesale price at $6.57 \%$ in the 30 th period. Other variables consisting of producer price, supply, and fuel price did not contribute significantly to consumer price movement. In the 30th period, the producer price, supply and fuel price contributed $0.50 \%, 0.84 \%$, and $1.41 \%$ respectively.

Earlier in the 15th period, the variables of wholesale price, producer price, supply, and fuel price contributed to the consumer price discovery at $6.47 \%, 0.53 \%$, $0.82 \%$ and $1.34 \%$ respectively. This result is in line with the study by Nurasa and Darwis in Ruslan (2016) which explained that the biggest advantage obtained by the economic actors in the red onion marketing chain from the production central region of Brebes District is retailers by transmitting prices from previous marketing institutions.

FEVD analysis was carried out to analyze the contribution of each variable. The consumer price of curly red chili was still influenced by the consumer price itself at $100 \%$ in the first period. In the following period, the contribution movement of each variable up to the 30th period showed that the wholesale price variable contributed the most at $13.40 \%$ in the 30th period. The same period also showed that the producer price, supply and fuel price contributed $2.07 \%, 0.13 \%$, and $1.44 \%$ respectively. In the preceding period of the 
15 th month, the variables of wholesale price, producer price, supply, and fuel price contributed to the retail price of curly red chili at $13.11 \%, 1.95 \%, 0.14 \%$, and $1.38 \%$ respectively.

Based on these results, it can be concluded that the variable that has the greatest contribution in influencing the consumer price movement of red onion and curly red chili commodities is the wholesale price variable. This statement is supported by the results of field interviews explaining that the selling price offered by retail merchants is most directly influenced by the wholesale price because the first information related to the selling price is obtained from the wholesale merchants themselves.

\section{The Strategies of Retail Merchants in the Price Discovery of Red Onion and Curly Red Chili}

The choice of action performed by a single retail merchant will influence the choice of action that will be implemented by other merchants. Based on the interviews, the strategies owned by retail merchants consist of two options comprising the application of selling price in accordance with the prevailing market price (market price strategy) or the application of lower selling price compared to the selling price implemented by other merchants (competitive price strategy). This study used seven retail markets in East Jakarta as samples for investigating the strategies used by the merchants in offering their selling prices to the consumers.

From Table 3, the gaming matrix between merchants in the determination of red onion and curly red chili prices in East Jakarta can be seen. Of the seven markets as the research samples, the nominal sale of Rp30,000 per $\mathrm{kg}$ became the price strategy option that was most widely taken up by the merchants. The high market price determined by the retail merchants leads to the high price paid by the consumers. The market behavior of red onion and chili has an effect on the behavior of imperfectly competitive market (Agnellia et al. 2016). Market information can encourage the latest information relating to market behavior.

Price changes also contribute to the selling price\%age those changes at the retail merchant level. Price increase signal receives more rapid response for retail merchants compared to the price decline because merchants avoid consumers' presumption against price fixing. This is supported by the studies conducted by Bakucs et al. (2014) and Greb et al. (2016) which explained that merchant behavior on price change response tends to be asymmetric, so price does not transmit perfectly because merchants try to maintain profit and avoid fluctuating selling price changes at any time.

Therefore, market price strategy is one of the optimal strategies to be implemented by merchants in offering the selling prices to the consumers. Market price as the payoff obtained by merchants will be greater than the payoff in the form of competitive price. Merchants will meet the optimal point of the Nash equilibrium when applying the market price that needs time in conducting changes even though the price at wholesale merchants has changed. This is done to avoid the allegation of price fixing because the commodity prices of red onion and curly red chili are responsive to the harvest season. Evenly distributed prices in a market reflect the price signaling with the formation of selling price equilibrium caused by the market power in the form of demand and supply power that is carried out by the economic actors in the market and provides the best payoff.

Most retail merchants conduct diversification in sales by not selling a single commodity in one stall to increase turnover. The magnitude of average cost component incurred by retail merchants is shifted to the composition of commodity selling prices, so the price load is given to the consumers.

\section{Managerial Implication}

Based on the results of the study there are managerial implications for several parties, namely: farmers, traders and regulators in terms of determining the commodity pricing policy of red onion and red chili, so that farmers and business actors can increase their profits. The results of this study, can provide input to farmers how the price movements on red onion and red chili commodities, as well as with traders so that it affects the behavior of market participants. For the government as a regulator, the results of this study can be used as a consideration in planning and policy making on commodities of shallots and red chili in Indonesia. In addition, also for researchers and the community, research can be a source of information that provides an overview of pricing and market behavior in the pricing of red onions and red chili. 
Table 3. The strategy matrix between merchants in the pricing of red onion and curly red chili in East Jakarta

\begin{tabular}{llr}
\hline \multirow{2}{*}{ Retailers 2} & \multicolumn{2}{c}{ Retailers 1} \\
\cline { 2 - 3 } Red onion & Competitive price & Market price \\
Market price & 26,$000 ; 30,000$ & 30,$000 ; 30,000^{*}$ \\
Competitive price & 26,$000 ; 26,000$ & 30,$000 ; 26,000$ \\
Curly red chili & & \\
Market price & 22,$000 ; 30,000$ & 30,$000 ; 30,000^{*}$ \\
Competitive price & 22,$000 ; 22,000$ & 30,$000 ; 22,000$ \\
\hline
\end{tabular}

Note: *Nash equilibrium

\section{CONCLUSIONS AND RECOMMENDATIONS}

\section{Conclusions}

Based on the research results, the conclusions derived are as follows: The variable responses that, as a whole, significantly and positively affect the consumer prices of red onion and curly red chili are the producer price and wholesale price. The variable with a significantly negative response is supply. Fuel cost variable has given different significant responses in both commodities. The pricing collusion becomes the preferred strategy adopted by retail merchants to maintain profits. Retail merchants have more power in determining the selling price because the expense incurred by retail merchants in kilogram is greater.

\section{Recommendations}

The recommendations related to the pricing system on red onion and red chili commodities from the study conducted are as follows: The consumer prices of red chili and red onion tend to fluctuate due to supply shocks and long marketing chain. Therefore, government intervention is needed in pricing. The policies from the government required for price stability can be made through direct pricing as well as through the guarantee of supply availability of red chili and red onion. Policy makers need to suppress the economic transaction costs in the marketing chain.

\section{REFERENCES}

[BPS East Jakarta] Statistic Center of East Jakarta City. 2016. Statistics of the Welfare of the People of East Jakarta. Jakarta: BPS
[PIKJ] Pasar Induk Kramat Jati. 2017. Prices, Supplies and Other Information Related to Horticulture at PIKJ. Jakarta: PIKJ.

[Pusdatin] Pusat data dan sistem informasi pertanian. 2015. Outlook of Commodity Shallot and Chili. Jakarta: Pusdatin Kementerian Pertanian.

Agnellia MADD, Ustriyana ING, Djelantik AAAWS. 2016. Analysis of the structure, conduct and performance of the chili market in Bayung Gede Village, Kintamani District, Bangli Regency. Journal of Agribusiness and Agritourism 5(1): $1-10$.

Agustian A, Anugrah IS. 2008. Analysis of price developments and marketing chains of red chili commodities in West Java Province. Bogor: Pusat Analisis Sosial Ekonomi dan Kebijakan Pertanian.

Amanda D. 2016. Market strength in the garlic trade in Indonesia [thesis]. Bogor: Institut Pertanian Bogor.

Ardito B. 2012. Market Structure, distribution, and formation of rice prices faculty of economics, University of Yogyakarta National Development "Veteran" North Ring Road Condongcatur, Yogyakarta. Journal of Economics and Development Studies 13(1): 24-32.

Bakucs Z, Falkowski J, Ferto I. 2014. Does market structure influence price transmission in the agro-food sector? A meta-analysis perspective. Journal of Agricultural Economics 65(1):1-25. https://doi.org/10.1111/1477-9552.12042.

Elvira. 2016. Transmission and formation of red chilli prices as well as market behavior among marketing agencies of red chili in Indonesia [thesis]. Bogor: Institut Pertanian Bogor.

Firdaus M. 2011. Aplikasi Ekonometrika untuk Data Panel dan Time Series. Bogor: PT Penerbit IPB Press.

Fitriana M. 2016. Vertical Price Transmission In Chili Market In Indonesia [thesis]. Bogor: Institut Pertanian Bogor.

Greb F, Jamora N, Mengel C, Cramon-T V. 2016. Price transmission from international to domestic markets. Report prepared for RPTG, DECAR, and PRMPR.

Indrawati. 2013. Analysis of the behavior of traders in developing prices for staple goods in the city of Pekanbaru. Economic Journal 21(1): 1-9.

Juanda B. 2009. Economic and Business Research Methodology. Bogor: IPB Press.

Kramat Jati Central Market. 2016. Chili Data and 
Tonage Data. Jakarta: Kramat Jati Central Market.

Nauly D. 2016. Fluctuation and price disparity of chili in Indonesia. Jurnal Agrosains dan Teknologi Fakultas Pertanian Universitas Muhammadiyah Jakarta 1(1): 56-69.

Njuguna SG. 2015. Cointegration of agricultural food prices in Nairobi country.

Nuraeni D, Anindita R, Syafrial S. 2015. Analysis of price variations and market integration of shallots in West Java. Universitas Brawijaya Journal 26(3): 163-172. https://doi.org/10.21776/ ub.habitat.2015.026.3.19.

Nuryati Y, Farid M. 2016. Analysis of the determination of the policy for the price of staple goods. Ministry of Trade's Agency for Trade Research and Development. National Seminar on Agricultural Development 2016: 193-199.

Paul UK, Gurudas D, Debnath A, Mathur T. 2016. Market integration and price leadership in India's onion market. SAGE Publications B(1\&2): 4964.

Rajendran S. 2015. Price transmission process in vertical markets: an Empirical analysis of onionmarkets in Tamil Nadu State (India). European Journal of Sustainable Development 4(1): 9-22. https:// doi.org/10.14207/ejsd.2015.v4n1p9.

Ruslan, JA. 2016. Price transmission and market behavior on shallots [thesis]. Bogor: Institut Pertanian Bogor.
Saptana, Daryanto A, Heny KD, Kuntjoro. 2010. Risk management strategy of red chili farmers in Lowland Rice Fields in Central Java. Jurnal Manajemen \& Agribisnis 7(2): 115-131.

Statistics Indonesia. 2015. Distribution and Population Density by District/city in DKI Jakarta Province. Jakarta: BPS.

Statistics Indonesia. 2016. Gasoline Prices by Province, 2011-2016. Jakarta: BPS.

Sujai M. 2016. Impact of fiscal policy in efforts to stabilize prices of agricultural commodities. Analisis Kebijakan Pertanian 9(4): 297-312. https://doi.org/10.21082/akp.v9n4.2011.297312.

Susanawati J, Masyhuri, Dwidjono. 2015. Integration of the shallot market in Nganjuk District (englegranger cointegration approach). Jurnal Agraris $1(1)$.

The Center for Data and Information System of the Ministry of Agriculture of the Republic of Indonesia. 2016. Outlook for onion commodities. Jakarta: Pusdatin Ministry of Agriculture.

The Indonesian Center for Agricultural Socioeconomic and Policy Studies (2015). Policy Analysis Report T.A. 2015. Global Macro Indicators and Agricultural Sector Outlook 2015-2019.

The Ministry of Agriculture of the Republic of Indonesia. 2017. Indonesia Inflation base on expenditure group. Jakarta: BPS. 